\title{
Same Same but Different: A history of the relationality between Aboriginal Australians and the Australian nation-state
}

\begin{abstract}
Alice Gordon
University of Technology Sydney, Faculty of Arts and Social Sciences, PO Box 123, Ultimo NSW

2017, Australia. alice.gordon@student.uts.edu.au

DOI: https://doi.org/10.5130/nesais.v4i1.1505

Abstract: The Australian polity's approach to Aboriginal and Torres Strait Islander people has historically emphasised integration into the colonial nation-state. This essay argues that these paternalistic principles continue to inform $21^{\text {st }}$ century policy to the detriment of meaningful progress towards coexistent Aboriginal sovereignty.
\end{abstract}

Keywords: Australian politics; Aboriginal sovereignty; self-determination; activism

Amanda Vanstone arguing to end 'separateness' between Indigenous and non-Indigenous Australians draws on ways of thinking that have guided public and political opinion for decades. Within her declaration she echoes past paternalistic policies by referring to Aboriginal Australians as 'ours', placing them as dependents of virtuous non-Indigenous authorities, incapable of self-determination. Vanstone made this statement in 2004 as then Minister for Immigration and Aboriginal Affairs, arguing to end the Aboriginal and Torres Strait Islander Commission (ATSIC), the only formal body made up of Aboriginal peoples to advise the government on issues relating to their lives. Beginning with the government policy of 'assimilation' in the early 1900s, many calls to see Aboriginal peoples integrated into a common Australia have been made by activists and politicians alike. The 1967 referendum was a marker of the public's opinion that Aboriginal people should be regarded as ordinary Australians citizens. Yet, Vanstone's belief that they "deserve to get the same treatment that everybody else gets" echoes decades of disregard for the complexity of Aboriginal citizenship. Activists fighting for citizenship were also concerned with the special provisions that were necessary to help Aboriginal people become equal citizens after almost 200 years of inequality and persecution. Furthermore, the $20^{\text {th }}$ century saw persecuted minorities recognising their difference as a starting point for demanding rights. Vanstone's emphasis on unity and the dismantling of ATSIC can be seen as acting to minimise the power of race-based activism. She campaigns against an alternative relationality presented by activists for distinct and sovereign Aboriginal nations living beside the nation-state of Australia.

Vanstone's comments are rooted in an era of increasing governmental control over Aboriginal lives. While she initially makes an attempt at appearing inclusive and advocating for a society without racial 
differences, her reference to First Nations peoples as 'ours' echoes the paternalistic 'Protection' policy of the early 1900s. 'Ours' suggests Aboriginal Australians are both external to the Australian population and that they are a possession for which white Australians are responsible. This is based on Social Darwinist beliefs which, although discredited in the 1930s and 1940s, continued to inform government policy and public opinion (Crawford 2013). School textbooks until the mid 1900s described Aboriginal people as "compliant, infantile and primitive" (Crawford 2013). Assumptions of their inferiority and the necessity of white intervention in their lives were attitudes that informed the 1909 'Protection' policy (Goodall 1995, p. 75). This saw Aboriginal people dispersed, banned from living in their communities, and later concentrated on reserves and missions with no choice over their living arrangements (Goodall 1995). Aboriginal Australians, positioned as childlike and incapable of self-determination, were viewed as dependants of virtuous white Australians, reliant on them for their 'protection' (Nicoll 2008, p. 63).

The earlier 'Protection' policy was replaced with the post-war Welfare Board's 'Assimilation' policy, although many of its most destructive powers were continued (Goodall 1995). It is here that Vanstone's contradictory statement, which places Aboriginal Australians as both 'ours' and as no different to the rest of Australia, is first enacted in State policy. The overarching belief of assimilation was that Aboriginal people could integrate into white society as equals, however the paternalist methods and beliefs of the 'Protection' policy informed this (Manning 2004). On reserves, Aboriginal people were contained until they had been resocialised to live in a way deemed acceptable by whites (Goodall 1995). Assimilation was based on the assumption that white lifestyles were superior and natural and placed Aboriginal people as 'hunters and gatherers' on the lowest social order (Goodall 1995, p. 63). Perhaps the most devastating example of this was the Aboriginal Protection Board's child removal policies, which saw children taken from Aboriginal communities to be integrated into white society with the hope that an Aboriginal presence in Australia could be bred out. This was justified by paternalistic attitudes arguing white Australians were 'saving' Aboriginal children from neglect (Goodall 1995). Again, Vanstone's idea of Aboriginal Australians as 'ours' is present in the view of them as dependents, with whites positioned as the who-knows-best guardian (Probyn 2003).

By the mid-1900s, the objectives of assimilation persevered in Australian polity and opinion, although with an increasing emphasis on national unity. Vanstone's rejection of 'separateness' reflects the liberal demand for equal citizenship that played a major part in the 1967 Referendum (Rowse 2000). The two core changes the referendum made to the Constitution, changing how Aboriginal people were counted in the census and allowing the Federal government to make laws on behalf of them, were not directly related to granting full citizenship rights. However, the specifics of the referendum were often lost in the overarching message put forth to the Australian public by 'yes' vote activists. Activists acknowledged that past referendums had been notoriously difficult to pass and seized upon a post-war attitude in favour of nation-building and citizenship to gain support for their cause (Bandler 1989, p. 104). Major Aboriginal activists often spoke in terms of the referendum ending discrimination and granting Aboriginal people full citizenship rights (Attwood \& Markus 1997, p. 49). Pamphlets often referred to a unified people with equality before the law. Activist Bill Onus stated that this was a matter of giving Aboriginal people the opportunity to become a part of the Australian community (Attwood \& Markus 1997). 
The referendum can be interpreted as an argument for assimilation and against difference: that, as Vanstone believes, Aboriginal people should not be placed in a different category (Attwood \& Markus 1997). Mid-century assimilation in this sense was a program of reform, envisaging a better world that put an end to segregation on reserves and missions. Aboriginal Australians could be guided towards emancipation and take part in national unity (Rowse 2000, p. 17). However, while many in the Aboriginal community did not believe that becoming full citizens meant sacrificing their Indigenous identity, this was not the belief shared by some within the wider community and Australian government (McGregor 2012). Public debate was focused on inclusion rather than ultimate right or sovereignty (Rowse 2000, p. 19). Minister for Territories, Paul Hasluck, believed that this inclusion required a shift from Aboriginal group life to a view of them as individuals or households. Assimilation, he believed, was slowed down by the retaining of Aboriginal identity and community (Rowse 2000, p. 23).

Vanstone's comments dismiss the calls made by the Aboriginal community for an end to discrimination and separateness without negating their Aboriginal identity. In the 1930s, assimilation was not rejected by all Aboriginal people in Australia, with some major activists such as William Cooper, Secretary of the Australian Aborigines' League, advocating in favour of it and pushing for Indigenous inclusion in the wider Australian community (McGregor 2012). However, they argued their inclusion in the nation and their Aboriginal identity went hand in hand. Their Aboriginal identity was cherished and put forth not as a liability to assimilation, but as an asset (McGregor 2012). At the 1967 referendum, these sentiments remained while the term 'assimilation' had waned in popularity. Activist Bert Groves stressed the desire to become part of the Australian community while simultaneously retaining an Aboriginal identity. Assimilation, he argued, was a mode of extermination and reflected an inability to accept minority groups as equal (Attwood \& Markus 1997). Respect was being demanded not only as an Australian, but also as an Indigenous Australian. However, mainstream discussions in white communities generally disregarded this. This rejection, as seen in Vanstone's opposition to separateness, has continued into the $21^{\text {st }}$ century (Attwood \& Markus 1997).

While there may be many reasons for the historical apprehension in recognising Indigenous 'separateness', one covert rationale is an aversion to the demands made by persecuted minorities for rights and provisions. Outlining Aboriginal Australians as distinct from the rest of the community led to discussion around the special provisions that were necessary to assist a group of people who had faced severe inequality (McGregor 2012). William Cooper advocated for these special conditions on the basis that it would improve equality, alongside the principle that "it is as unjust to treat unequals equally as to treat equals unequally" (Rowse 2000, p. 20). It is here that Vanstone's belief that Indigenous Australians "deserve to get the treatment that everybody else gets" goes beyond assimilation discourse to actively reject calls made by Aboriginal Australians to receive additional provisions based on their position. Yet, Vanstone's apprehension to acknowledge the necessity of special treatment for Aboriginal Australians is not an anomaly in race relations historically. The idea of racial resentment, originally coined in the U.S., can be used to describe the belief that people of colour are undeserving of any special assistance (Feldman \& Huddy 2005). It suggests that all people are given the same rights and opportunities and that, if a minority faces particular inequality, cultural elements or an inability to take advantage of opportunities is the cause (Feldman \& Huddy 2005). 
The emergence of racial resentment can be dated back to the race riots of the 1960s, a time when black political demands were growing (Feldman \& Huddy 2005). In Australia, the emphatic opposition to specific Indigenous provisions can be linked to the increased demands made after the referendum, such as land rights (Ginsberg \& Myers 2006). Vanstone's call for unity, when looked at in the context of shutting down ATSIC, can be viewed along similar lines. Calling for equal treatment while closing off the only body for Aboriginal and Torres Strait Islander peoples to be involved in law-making pertinent to their lives echoes efforts made in past decades to block the formation of potentially powerful race-based groups. In 1920s Australia, Aboriginal people became aware of increasing black protest and ideas from visiting seamen, international figures such as Jack Johnson and newspapers like Negro World (Maynard 2005). A pride in Indigeneity and the demands that could follow were threatening to white authorities who sought to limit the circulation of such newspapers (Maynard 2005). These demands continued to grow, particularly in the aftermath of the referendum when many activists moved their focus from the liberal idea of citizenship to Indigenous rights and land (Attwood \& Markus 1997). The emphasis on their Indigenous identity was ever-increasing. The referendum, some said, had eased the guilt of white Australia without making any real changes for Aboriginal Australians (Attwood \& Markus 1997). For Aboriginal Australia, it was a necessary symbolic gesture that would pave the way for progress in Indigenous affairs. In the advent of Vanstone's comments, it is clear this history of race-based activism, and the opposition of white authorities to it, continues (Nicoll 2008).

Vanstone's rhetoric reflects her resistance to alternative relationalities between Aboriginal and nonAboriginal Australia. One significant view sees distinct and sovereign Aboriginal nations that co-exist alongside the Australian nation (Osuri 2009). This view existed in mainstream Aboriginal activism during the Assimilation policy, with activists such as Cooper calling for pride in a distinct Indigenous identity, but gained greater momentum and emphasised sovereignty after the 1967 Referendum (McGregor 2009) (Martinez 2009). Building a nation of their own became more significant than the fight for inclusion within white Australia. This coincided with the 1960s emphasis on empowerment and liberation and a push for distinct Indigenous rights (McGregor 2009, p. 343). In 1972, the establishment of the Aboriginal Tent Embassy on the lawns of Parliament House made clear the desire for a kind of separateness (Martinez 2009). Sovereignty, or supreme ruling power, had never been ceded by Indigenous Australians. They remained, and remain, sovereign people part of many Aboriginal nations that govern themselves (Moreton-Robinson 2007). Sovereignty within Aboriginal communities is not legally recognised by the Australian government (Osuri 2009); it is based on ways of governing that pre-existed European contact and is not reliant on state intervention and paternalism (Osuri 2009). It differs from Western attitudes towards sovereignty that are founded on a social contract model and emphasise individual rights and a supreme authority (Moreton-Robinson 2007). Aboriginal sovereignty is embodied and is based on the relationships between humans, land and ancestral beings. These different understandings have contributed to white Australia refusing to accept Aboriginal sovereignty as legitimate and serious (Moreton-Robinson 2007).

An acceptance of Aboriginal sovereignty is fundamental in building a new understanding of the relationality existing in Australia between colonisers and First Nations Peoples. A sovereign nation means Aboriginal Australians are not 'ours' nor indistinct Australian citizens. Nonetheless, supporters do not deny that the nation-state of Australia is dominated by political, economic, social and cultural structures that are based on colonial sovereignty (Martinez 1997). Indigenous and non-Indigenous 
Australians are already co-existing in a temporal and spatial sense (Osuri 2009). However, the terms under which they co-exist are based on non-Indigenous arrangements and are therefore unequal (Osuri 2009). Current discourses argue it is possible to live as sovereign Aboriginal people at the same time as existing within a sovereign colonial Australia (McGregor 2009, p. 345) (Osuri 2009), and that Aboriginal and non-Aboriginal people can live side-by-side while remaining distinct (McGregor 2009). This was somewhat legitimised by the advent of the government's multiculturalism policy in the 1970s, which accepted the notion of nations living within a nation (Martinez 1997, p. 135). The legitimacy of an Aboriginal sovereign nation is not depleted by recognising the dominance of a colonial Australian nation which regards itself sovereign (Osuri 2009).

Vanstone actively continues a tradition of colonial authorities using the promise of equality and desegregation to disband influential Aboriginal voices calling for independent rights and sovereignty. Her positioning of Indigenous peoples as 'ours' contradicts her assertion of them as the same, reflecting past paternalistic attitudes seen most explicitly in the government's 'Protection' policy. This contradiction also echoes processes which saw non-Indigenous authorities arguing for 'assimilation' while at the same time placing themselves as the responsible guardians of a child-like Aboriginal population. Her desire for an end to 'separateness' is not, however, completely divorced from the desires of Aboriginal activists, many of whom campaigned for equal citizenship during the 1967 Referendum campaign. Yet, by drawing on the mainstream arguments of the 1960s, she does not engage with the requests made by activists to be regarded as different insofar as recognising the unique needs they had to reach equal citizenship. It also dismisses the advancements made in Aboriginal rights discourses which moved beyond inclusion to advocate for land rights and sovereignty. The dissolution of ATSIC is part of a history of white authorities viewing distinctive Indigenous groups as a threat due to their influence in advocating for these rights. An alternative to complete unity comes in the form of Aboriginal sovereignty, which recognises Aboriginal and Torres Strait Islander peoples as responsible for their own affairs. Furthermore, this does not actively push for a divide, but suggests that sovereign Aboriginal people can live within and side-by-side with the colonial sovereign state of Australia.

\section{References}

Attwood, B. \& Markus, A. 1997, 'Chapter 6: Aboriginal Perceptions' in The 1967 Referendum, Aboriginal Studies Press, Canberra, pp. 49-63.

Bandler, F. 1989, 'The Referendum', in Turning the tide: a personal history of the Federal Council for the Advacement of Aborigines and Torres Strait Islanders, Canberra, Aboriginal Studies Press, pp. 79-110.

Crawford, K. 2013, 'Constructing Aboriginal Australians, 1930-1960: Projecting False Memories', vol, 5, no. 1, pp. 90-107. https://doi.org/10.3167/jemms.2013.050106

Feldman, S. \& Huddy, L. 2005, 'Racial Resentment and White Opposition to Race-Conscious Programs: Principles or Prejudice?', Midwest Political Science Association, vol. 49, no. 1, pp. 168183. https://doi.org/10.1111/j.0092-5853.2005.00117.x

Ginsberg, F. \& Myers, F. 2006, 'A History of Aboriginal Futures', Critique of Anthropology. Vol. 26, no. 1, pp. 27-45. https://doi.org/10.1177/0308275X06061482 
Goodall, H. 1995, 'New South Wales', in A. McGrath (ed.), Contested Ground: Australian Aborigines Under the British Crown, Sydney, Allen \& Unwin, pp. 55-120.

Manning, C. 2004, 'A Helping White Hand' : Assimilation, Welfare and Victoria's Transitional Aboriginal Housing Policy', Labour History, no. 87, pp. 193-208. https://doi.org/10.2307/27516006

Martinez, J. 1997, ‘Problematising Aboriginal nationalism', Aboriginal History, vol. 21, pp. 133-147.

Maynard, J. 2005, “'In the interests of our people': the influence of Garveyism on the rise of Australian Aboriginal political activism', Aboriginal History, vol. 29, pp. 1-22.

McGregor, R. 2009, 'Another Nation: Aboriginal Activism in the Late 1960s and Early 1970s', Australian Historical Studies, vol. 40, pp. 343- 360. https://doi.org/10.1080/10314610903105217

McGregor, R. 2012, 'Aboriginal Activists Demand Acceptance', Indifferent Inclusion: Aboriginal People and the Australian Nation, Canberra, Aboriginal Studies Press, pp. 37-54.

Moreton-Robinson, A. 2007, 'Introduction', Sovereign Subjects: Indigenous Sovereign Matters, Allen \& Unwin, Sydney.

Nicoll, F. 2008, 'Consuming Pathologies: The Australian against Indigenous sovereignties', in A. Moreton-Robinson, M. Casey \& F. Nicoll (eds), Transnational whiteness matters, Lexington Books, Lanham, pp. 57-79.

Osuri, G. 2009, '(Im)possible co-existence: notes from a bordered, sovereign present', Borderlands, vol. 8 , no. 1, pp. 1-21.

Probyn, F. 2003, 'the white father: Denial, Paternalism and Community', Cultural Studies Review, vol. 9, no. 1, pp. 60-76. https://doi.org/10.5130/csr.v9i1.3584

Rowse, T. 2000, 'The Modest Mandate of 1967', in Obliged to be difficult: Nugget Coombs' Legacy in Indigenous Affairs, Cambridge, Cambridge University Press, pp. 17-33.

https://doi.org/10.1017/CBO9780511552199.002

(c) (1) (C) 2018 by the author(s). This article is distributed under the terms and conditions of the Creative Commons Attribution license (http://creativecommons.org/licenses/by-nd/4.0/). 